\title{
Identification of Key Factors for Selection of Accounting Specialization by Students at Public Higher Education Institutions in Bosnia and Herzegovina
}

\author{
Amra Gadžo \\ Faculty of Economics, University of Tuzla, Bosnia and \\ Herzegovina \\ amra.gadzo@untz.ba

\section{Benina Veledar} \\ School of Economics and Business, University of Sarajevo, \\ Bosnia and Herzegovina \\ benina.veledar@efsa.unsa.ba

\section{Srđan Lalić} \\ Faculty of Economics, University East Sarajevo, Bosnia and \\ Herzegovina \\ srdjan.lalic.efb@gmail.com
}

\author{
CroEconSur \\ Vol. 23 \\ No. 1 \\ June 2021 \\ pp. 5-29
}

Received: July 21, 2020

Accepted: March 17, 2021

Research Article

doi:10.15179/ces.23.1.1

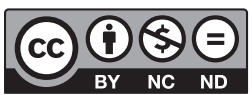

\section{Abstract}

The paper aims to investigate the influencing factors for the choice of accounting specialization by students at ten public higher education institutions in Bosnia and Herzegovina $(\mathrm{BiH})$. In addition to the above, the paper also explores the gender structure of the students, the type of secondary education, the time of making the decision to choose the field of accounting, and planned future training in accounting. The research sample consisted of 253 respondents, and data collection was performed by electronic survey through distance learning platforms. To identify the key factors in choosing to study accounting, we used the multivariate method of factor analysis of major components. 
The results of the research point to the existence of four key influencing factors in the selection of accounting specialization: achievement, job fulfillment, the influence of authorities in the field of science and profession, and the influence of parents and friends. Over 77 percent of the students are women, and the students have mostly completed general high schools (gymnasiums) or high schools of economics (92 percent). More than 98 percent of the students plan to continue their training in the field of accounting.

The results of the research have practical use in terms of preparation and presentation of accounting policies at public higher education institutions in $\mathrm{BiH}$, given that the reduced number of students has resulted in rival positions among different study areas. The results of the research can also be useful to professional groups in the field of accounting in terms of achieving their strategic goals.

Keywords: influencing factors, accounting profession, public higher education institutions, Bosnia and Herzegovina

JEL classification: M40, M49

\section{Introduction}

Bosnia and Herzegovina ( $\mathrm{BiH})$, like most other countries in Southeast Europe, has been facing a steady decline in population over the past few decades, with citizens emigrating to more developed countries for social and political reasons. Another reason for the rapid decline in population lies in the fact that $\mathrm{BiH}$ has the lowest birth rate compared to other European countries. Such negative trends have also affected the number of students studying at public higher education institutions in $\mathrm{BiH}$. Although the percentage of high school students enrolling in higher education institutions is growing, the number of students is declining in absolute terms. The establishment of an increasing number of private higher education institutions also contributes to such indicators. 
The declining trend in the number of enrolled students has had a direct impact on the declining number of students majoring in accounting and auditing. At the same time, even the privileged position of students in accounting study programs in terms of the reduction of exams for acquiring a degree in the accounting profession, failed to stop this negative trend. When it comes to ranking the study programs by the number of students, we have a differentiated picture of public higher education institutions in $\mathrm{BiH}$. In most cases where we have a small number of specializations in the final years, the field of accounting is still the most numerous. On the other hand, at faculties where there are five specializations in the final years, the field of accounting ranks second or third in terms of student numbers.

It is evident that the study specializations at the faculties have a rival position, and that members of the teaching staff, from the first year of studies onward, promote their subjects to the students through lectures and exercises. Due to exactly these reasons, this research attempts to reveal the key factors influencing the choice of accounting specialization made by students, at what moment students make this decision, whether the type of completed high school has an influence on the choice, and so on.

\section{Theoretical Research Framework}

Each student is unique in terms of place of upbringing and cultural and historical heritage, attitudes and perceptions of the family in which one grows up, economic situation of a household, relatives and friends around him or her, level of personal education, character, attitudes, preferences, and desires. We may say that the choice of a student's profession is influenced by several key factors such as: personal and cultural values, influential family factors, expectations of future career, societal attitudes about a particular occupation, and so on. These influential factors may be divided into three groups: extrinsic, intrinsic, and interpersonal. 
This three-dimensional classification of factors influencing future career choice was set up by Carpenter and Foster (1977) and Beynon, Toohey, and Kishor (1998). In this case, extrinsic factors are situational, that is, contextual factors. Intrinsic factors are motivating factors related to a certain job, while interpersonal factors represent the influence of other people on decision making.

A large number of authors have based their research on influencing factors of career choice based on this three-dimensional classification (Agarwala, 2008; Abbasi \& Sarwat, 2014; Marinas, Igret, Marinaș, \& Prioteasa, 2016; Jamil, 2019; Nwobi, Uzoekwe, Ojo, \& Odo, 2020; and others).

\section{Literature Review}

It is widely believed, particularly by students, that the selection of study programs is the major factor that leads students to their desired future career (Theresa, 2015; Nimra, Nawaz, \& SamiUllah, 2019). When it comes to analyzing the selection of an accounting specialization at a university, or an accounting profession in the future, there is a large number of various studies that are not uniform in their conclusions. A number of scientists emphasize that intrinsic factors are the most influential ones. According to a study conducted by Jamil (2019), the most influential factors in choosing a career are intrinsic factors, while interpersonal factors are the least influential. As stated in a study conducted by Azrinawati, Khalil, Saidin, Kadir, and Romaino (2018), four significant factors are taken into account when choosing a certified accountant profession: intrinsic factors, extrinsic value, race, and cumulative grade point average (CGPA). Among these, the intrinsic factors are the most influential. Research results from a study conducted by Dibabe, Wubie, and Wondmagegn (2015) show that intrinsic factors are the most influential when choosing an accounting specialization in Ethiopia. According to a study conducted by T,icoi and Albu (2018), the most important group of factors in choosing an accounting career in Romania includes intellectual motivation, followed by relational and financial incentives. 
A number of authors emphasize that extrinsic factors are the most important in making the decision to choose an accounting career. According to a study conducted by Porter and Woolley (2014) on the factors influencing the choice of accounting major in the United States, accounting students have a primary goal of career achievement, and less emphasis is placed on intrinsic factors of this type of work. That is, extrinsic factors (financial benefits and job stability) are a greater motive for choosing an accounting career than intrinsic factors (job satisfaction). According to a study conducted by Kamran, Kazi Feroz, and Manzurul (1997) on students from five universities in New Zealand, students choose an accounting career primarily based on extrinsic factors, while intrinsic factors have a much smaller impact. Similar research results were obtained by van Zyl and de Villiers (2011). According to a survey conducted among students in Indonesia (Hartutik, Hendra, \& Masitoh, 2016), only the motive of career achievement has a significant impact on students' choice to study for the accounting profession, while the quality of studies, economic motives, social motives, and the degree of education have no influence on the choice. Also, according to a study conducted by Akter and Siraj (2018) among students in Bangladesh, the lower income level of the family from which the student comes has an impact on the choice of accounting career. In a study conducted by Hartati (2019) in Indonesia, the author concludes that only the motive of study quality plays an important role in choosing to study for an accounting career, while other motives such as economic factors, career, achievement, and social class have no significant influence on that choice. The author also emphasizes that the results of this study are significantly different from the results of research for other countries. A study by Byrne et al. (2012) conducted at universities in four European countries (Ireland, UK, Spain, and Greece) concludes that for students in the UK and Spain, career focus is the most influential factor in choosing an accounting specialization, followed by intellectual growth as the second-ranked factor. On the other hand, in students from Ireland and Greece, the order of importance of these factors is reversed, that is, intrinsic factors are more important than extrinsic ones. 
A number of scientists emphasize that interpersonal influences are the most significant when choosing an accounting career. This is supported by the results of a study conducted in Malaysia by Ibrahim, Pauzi, Shamsudin, Karim, and Ahmad (2017). They conclude in their research that there are four key factors that are significant in the choice of accounting specialization by students, with parental influence being the most significant. They based their research on influencing factors classified into three groups, namely: extrinsic, intrinsic, and interpersonal influencing factors. According to a study by Hashim and Embong (2015), who analyzed the level of influence of parents and peers on the choice of accounting career of Malaysian high school students, the results reveal that parents, mothers in particular, are more influential in the career choice of the high school students compared to their peers. According to a study conducted by Rababah (2016) in ten universities in the United Arab Emirates, family members and peers significantly influence students' choice of accounting as a major. The findings of the study reveal that personal interests, personality, job prospects, reputation of the university, and media do not have a significant influence on the students' choice of an accounting specialization. According to Nwobu, Faboyede, and Oyewo (2015), there is a great gap in Nigeria between students who choose work in practice (70.7 percent) and those who choose further academic development (28.7 percent). The remaining 0.6 percent of students do not desire to continue their career in the accounting profession.

\section{Objectives, Sample, and Research Methodology}

The main research objective is to identify the key factors that influence the selection of accounting specialization by students of public higher education institutions in $\mathrm{BiH}$. Also, we will rank the influence of extrinsic, intrinsic, and interpersonal factors. Besides these two main research objectives, we will also research the following: 
- the gender structure and type of secondary education of students who have opted for accounting at public higher education institutions in $\mathrm{BiH}$;

- when students made the decision to select the accounting specialization; and

- attitudes of students about their planned training in the field of accounting after graduation.

The research population consists of students from ten public higher education institutions in $\mathrm{BiH}$ in the field of economics. These are third and fourth year students who have chosen an accounting major for further studies. At most public higher education institutions, the accounting program is called "Accounting and Auditing" or "Finance and Accounting". There were no respondents from the Faculty of Economics, University Džemal Bijedić Mostar in the research population because the accounting program is not active. On the other hand, at the Faculty of Business Economics in Bijeljina, there are no specializations in the final years. Therefore, the sample included those students who expressed a preference for a future career in the accounting profession. The same criterion was applied to other higher education institutions that have a joint specialization program for accounting and finance.

The sample consists of 253 respondents, which on average makes up over 35 percent of the total population of students in accounting specializations and students who plan to pursue a career in accounting (Table 1). The collection of primary data was done in March 2020 through an online survey via distance learning platforms (during the crisis caused by the COVID-19 pandemic).

Data processing was performed by descriptive and multivariate analysis. The identification of key factors in the selection of accounting specialization was done by applying factor analysis. We have identified 16 key influencing factors that are divided into three groups: extrinsic, intrinsic, and interpersonal influencing factors. Each of the given factors was assessed by the students using the Likert scale with five divisions. 
Table 1: Structure of the Research Sample

\begin{tabular}{l|c|c}
\hline Public higher education institution in BiH & $\boldsymbol{F}$ & $\mathbf{\%}$ \\
\hline School of Economics and Business in Sarajevo & 38 & 15.02 \\
\hline Faculty of Economics in Pale & 21 & 8.30 \\
\hline Faculty of Economics in Banja Luka & 11 & 4.35 \\
\hline Faculty of Economics, University in Mostar & 57 & 22.52 \\
\hline Faculty of Economics, University Džemal Bijedić in Mostar & 0 & 0.00 \\
\hline Faculty of Economics in Tuzla & 41 & 16.21 \\
\hline Faculty of Economics in Zenica & 23 & 9.09 \\
\hdashline Faculty of Business Economics in Bijeljina & 24 & 9.49 \\
\hline Faculty of Economics in Bihać & 23 & 9.09 \\
\hline Faculty of Economics in Brčko & 15 & 5.93 \\
\hline Total & $\mathbf{2 5 3}$ & $\mathbf{1 0 0 . 0 0}$ \\
\hline
\end{tabular}

Source: Authors' calculations.

By extrinsic factors we imply situational, that is, contextual factors, which consist of five set variables:

- expected level of future income,

- expected position in the company,

- expected position in society,

- expected quality of study, and

- the possibility of reduction of exams for acquiring a degree in the accounting profession.

By intrinsic factors we imply motivating factors related to the work being done, and they consist of five set variables:

- expected job satisfaction,

- expected opportunities for future career development,

- expected employment opportunity,

- personal enthusiasm and talent, and 
- the general attitude that knowledge of accounting is the foundation of a good economist.

By interpersonal factors we imply the influence of other people on students' decision making. We set six variables in interpersonal factors, as follows:

- parental influence,

- influence of friends,

- influence of teachers and associates,

- influence of prominent accounting practitioners,

- influence of economists from another field, and

- career conversation and professional orientation.

\section{Research Results and Discussion}

\subsection{Gender Structure and Completed Secondary Education}

In the total sample, female students make up 76.7 percent (194 respondents), while male students make up only 23.3 percent (59 respondents). Therefore, it can be concluded that jobs in the field of accounting are mostly related to women (Figure 1). A fact that contributes to this situation is the gender structure of students enrolling in faculties of economics, where female students generally predominate.

If we look at the secondary education of students in accounting specializations at public higher education institutions in $\mathrm{BiH}, 62.8$ percent graduated from high schools of economics, 29.6 percent from gymnasiums (general high schools), 4 percent from technical high schools, and 3.6 percent from other schools (Figure 2). 
Figure 1: Gender Structure of Students in Accounting Specializations

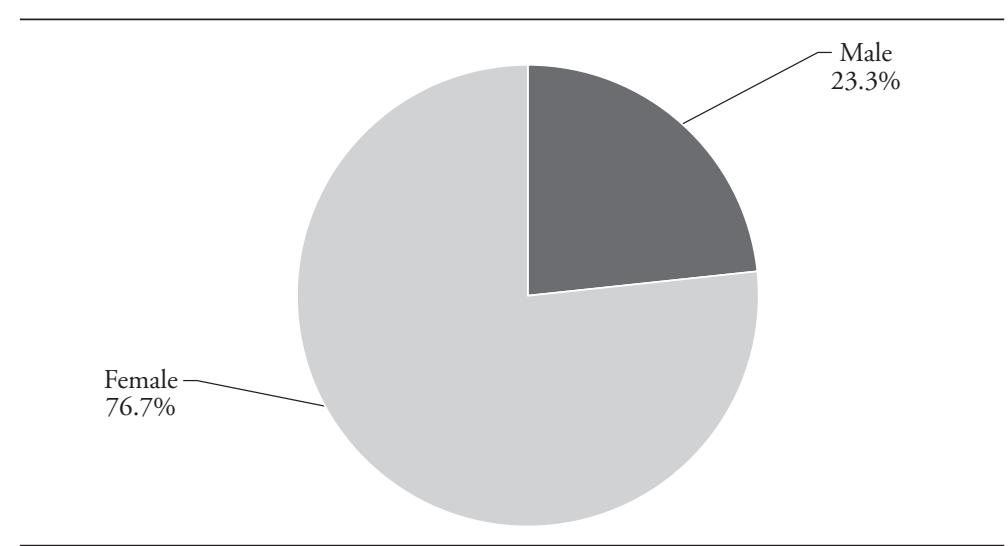

Source: Authors' calculations.

Figure 2: Type of Secondary Education of Students in Accounting Specializations

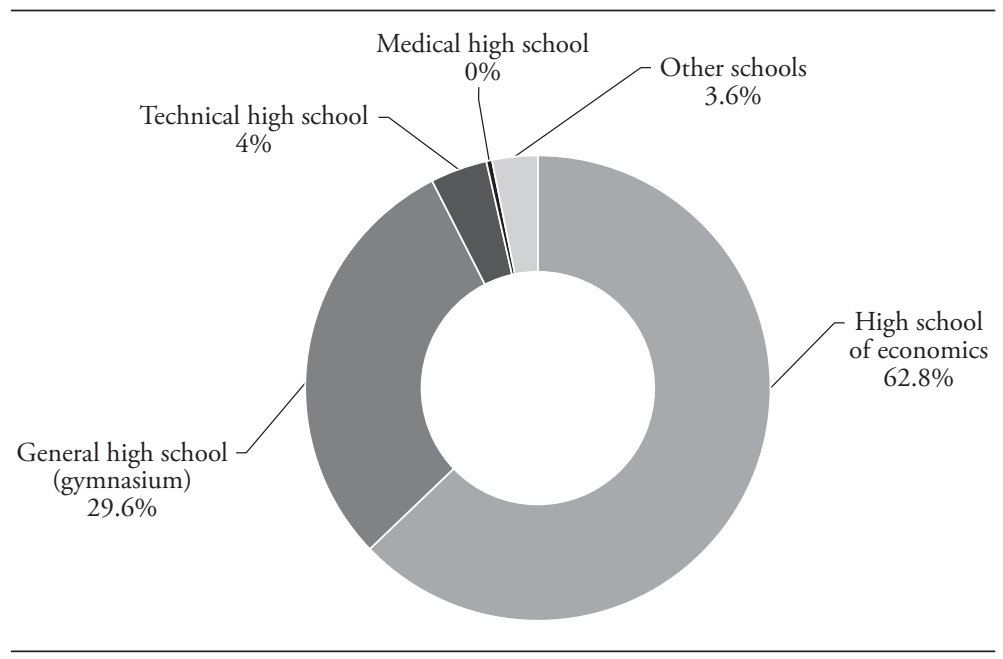

Source: Authors' calculations.

Given that in the last few years there has been a drastic increase in the number of students enrolling and graduating from medical schools (due to planned 
emigration), we also investigated how many of them continued to study economics with a focus on accounting. The results show that only one student ( 0.4 percent) of the 253 students in the sample continued to study economics with a focus on accounting.

\subsection{Identification of Key Influencing Factors in Selecting an Accounting Specialization}

Through observation of the descriptive statistical analysis (Table 2), we may conclude that intrinsic factors have the greatest influence when selecting an accounting specialization in public higher education institutions in $\mathrm{BiH}$, followed by extrinsic factors, while interpersonal factors have the least influence. The average grade for intrinsic factors is 4.12 cumulatively, for extrinsic factors 3.98 , and for interpersonal factors 2.59 .

Through observation of the average and standard deviation, we may notice that certain variables have greater values than others within those three groups of influencing factors. Within the intrinsic factors, the greatest grade is held by the variable "Various opportunities for future career development", within the extrinsic factors, the greatest grade is held by the variable "Level of future income (earnings)", and within the interpersonal factors, the greatest grade is held by the variable "Career conversation and professional orientation". We have tested if there is a difference between the attitudes of women and men, as per these key variables. The conclusion of this analysis is that we have not found statistically significant differences between the attitudes of women and men.

Even though we have used descriptive statistics to extract variables within the intrinsic, extrinsic, and interpersonal influencing factors for the choice of accounting specialization, without factor analysis, it is not possible to identify the key influencing factors. In order to identify the key influencing factors for the choice of accounting specialization, we applied the multivariate method of factor analysis of principal components - principal component analysis (PCA). 
Table 2: Descriptive Statistical Analysis

\begin{tabular}{|c|c|c|c|c|c|c|}
\hline & $N$ & Minimum & Maximum & Sum & Average & $\begin{array}{c}\text { Std. } \\
\text { deviation }\end{array}$ \\
\hline Intrinsic_job satisfaction & 253 & 2.00 & 5.00 & $1,025.00$ & 4.0514 & .93929 \\
\hline $\begin{array}{l}\text { Intrinsic_various } \\
\text { opportunities for future } \\
\text { career development }\end{array}$ & 253 & 1.00 & 5.00 & $1,094.00$ & 4.3241 & .88958 \\
\hline $\begin{array}{l}\text { Intrinsic_possibility of } \\
\text { employment }\end{array}$ & 253 & 1.00 & 5.00 & $1,034.00$ & 4.0870 & .98417 \\
\hline $\begin{array}{l}\text { Intrinsic_personal } \\
\text { enthusiasm and talent }\end{array}$ & 253 & 1.00 & 5.00 & 965.00 & 3.8142 & .97645 \\
\hline $\begin{array}{l}\text { Intrinsic accounting is } \\
\text { the foundation of a good } \\
\text { economist }\end{array}$ & 253 & 1.00 & 5.00 & $1,090.00$ & 4.3083 & .96764 \\
\hline $\begin{array}{l}\text { Extrinsic_level of future } \\
\text { income (earnings) }\end{array}$ & 253 & 1.00 & 5.00 & $1,051.00$ & 4.1542 & .82853 \\
\hline $\begin{array}{l}\text { Extrinsic_position in the } \\
\text { company }\end{array}$ & 253 & 1.00 & 5.00 & $1,014.00$ & 4.0079 & .85446 \\
\hline $\begin{array}{l}\text { Extrinsic_position in } \\
\text { society }\end{array}$ & 253 & 1.00 & 5.00 & 900.00 & 3.5573 & 1.07722 \\
\hline $\begin{array}{l}\text { Extrinsic_quality of study } \\
\text { specialization }\end{array}$ & 253 & 1.00 & 5.00 & $1,039.00$ & 4.1067 & .94306 \\
\hline $\begin{array}{l}\text { Extrinsic_reduction for } \\
\text { acquiring a degree in } \\
\text { accounting profession }\end{array}$ & 253 & 1.00 & 5.00 & $1,032.00$ & 4.0791 & .90066 \\
\hline $\begin{array}{l}\text { Interpersonal_influence } \\
\text { of parents }\end{array}$ & 253 & 1.00 & 5.00 & 531.00 & 2.0988 & 1.25124 \\
\hline $\begin{array}{l}\text { Interpersonal_influence } \\
\text { of friends }\end{array}$ & 253 & 1.00 & 5.00 & 452.00 & 1.7866 & 1.05874 \\
\hline $\begin{array}{l}\text { Interpersonal_influence } \\
\text { of teachers and associates }\end{array}$ & 253 & 1.00 & 5.00 & 633.00 & 2.5020 & 1.25238 \\
\hline $\begin{array}{l}\text { Interpersonal_influence } \\
\text { of prominent accounting } \\
\text { practitioners }\end{array}$ & 253 & 1.00 & 5.00 & 703.00 & 2.7787 & 1.37668 \\
\hline $\begin{array}{l}\text { Interpersonal_influence } \\
\text { of economists from } \\
\text { another field }\end{array}$ & 253 & 1.00 & 5.00 & 713.00 & 2.8182 & 1.27185 \\
\hline $\begin{array}{l}\text { Interpersonal_career } \\
\text { conversation and } \\
\text { professional orientation }\end{array}$ & 253 & 1.00 & 5.00 & 901.00 & 3.5613 & 1.20893 \\
\hline Valid $N$ (listwise) & 253 & & & & & \\
\hline
\end{tabular}

Source: Authors' calculations.

PCA is a method that reduces dimensionality, and is used to achieve visibility and simplify a large amount of data. The aim of the factor analysis is to explain the 
interconnection of a large number of variables with a smaller number of latent variables, for example, sources of covariances.

To examine the suitability of the data for factor analysis, we used the Kaiser-MeyerOlkin measure of sampling adequacy (KMO) and Bartlett's test of sphericity (Table 3). A KMO value of 0.862 indicates the suitability of the correlation matrix for factor analysis. On the other hand, the values of significance parameters from the Bartlett's test indicate the existence of a significant correlation among the original variables.

Table 3: Sample Suitability Test for Factor Analysis

\begin{tabular}{|c|c|c|}
\hline \multicolumn{2}{|c|}{ Description } & Value \\
\hline \multicolumn{2}{|c|}{ Kaiser-Meyer-Olkin measure of sampling adequacy } & .862 \\
\hline \multirow{3}{*}{ Bartlett's test of sphericity } & Approx. chi-square & $1,657.814$ \\
\hline & $d f$ & 120 \\
\hline & Sig. & .000 \\
\hline
\end{tabular}

Source: Authors' calculations.

We have singled out the utilities of all 16 factors. The communalities of all factors in this study are decently high and range from 0.508 to 0.775 . In doing so, it is important to emphasize that the higher the utility, the more known the variable.

Table 4 shows the results of factor extraction. The table shows the eigenvalues for the extracted factors as well as the values for the total variance. The eigenvalues for the four extracted factors are 5.580 (first factor), 2.364 (second factor), 1.295 (third factor), and 1.086 (fourth factor). This implies that the first four factors have critical values greater than 1 , and these four factors explain 64.53 percent of the variance. It can be seen that the percentage of total variance for the relevant factors is higher than 60 percent, which is the lower allowed limit in social research. 


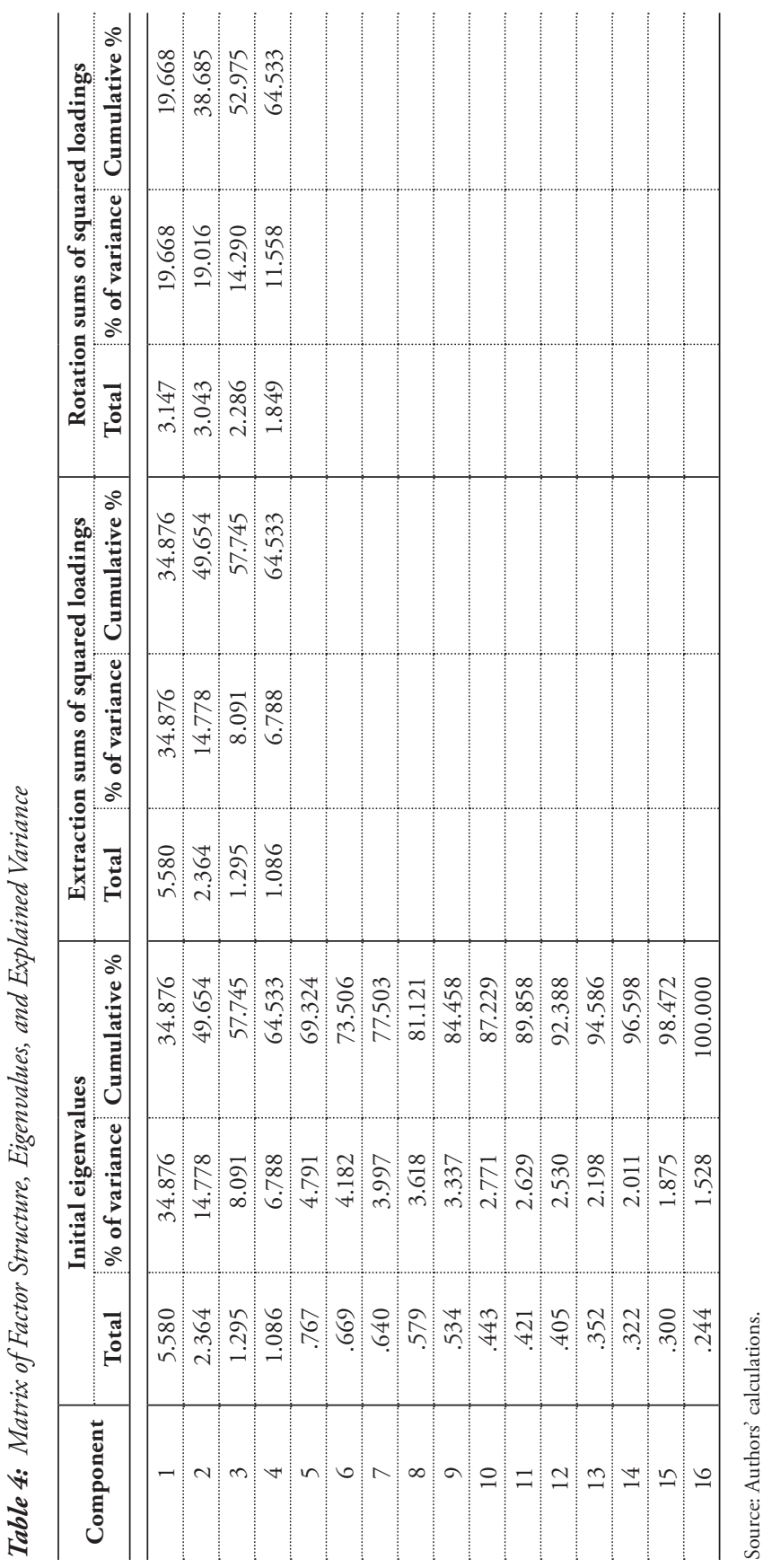


According to the scree plot criterion based on the Cattell diagram, a break between factors four and five is visible, which confirms the separation of four factors, because their eigenvalues are separated from the eigenvalues of the remaining factors (Figure 3). More specifically, the fracture of the diagram at the junction of the fourth and fifth factors is visible, which implies the conclusion that the first four factors explain a much higher percentage of variance than the remaining factors.

Figure 3: Cattell's (Scree Plot) Diagram of the Expectation Scale

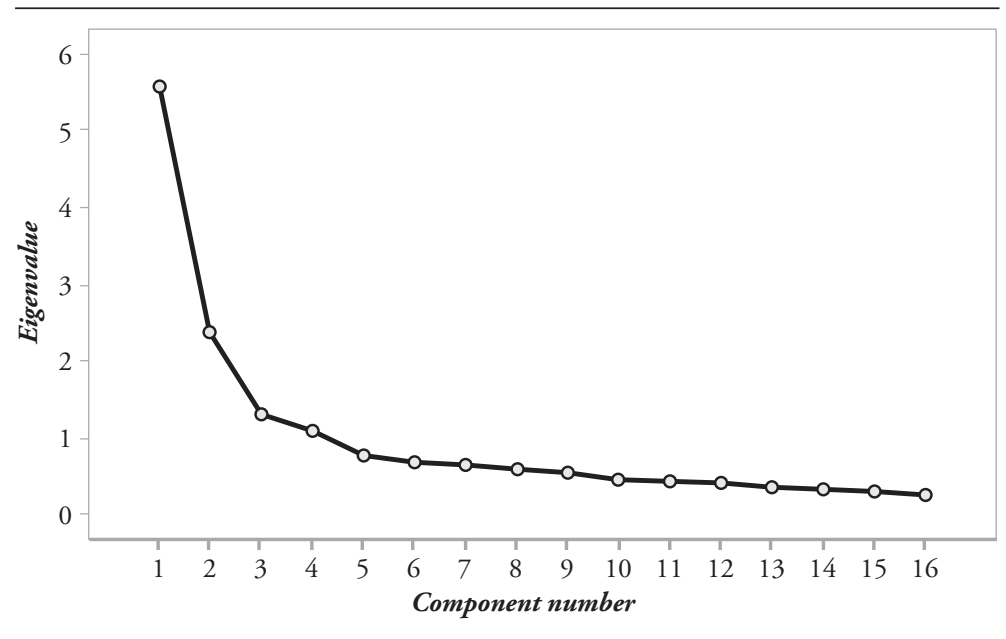

Source: Authors' calculations.

After factor extraction, orthogonal factor rotation was performed using the "varimax rotation with Kaiser normalization" method, which aims to ensure that each variable is representative with as few factors as possible and the best possible spatial dispersion.

Table 5 shows the factor structure matrix for 16 variables after the varimax factor rotation was performed. The results show that the structure of factor loads has changed, i.e., that factor loads are distributed on all four factors: 
Table 5: Factor Structure Matrix After Orthogonal Varimax Factor Rotation

\begin{tabular}{|c|c|c|c|c|c|}
\hline \multirow{2}{*}{ No. } & \multirow{2}{*}{ Question (variable) } & \multicolumn{4}{|c|}{ Factor structure } \\
\hline & & 1 & 2 & 3 & 4 \\
\hline 1 & Extrinsic_position in the company & .847 & & & \\
\hline 2 & Extrinsic_level of future income (earnings) & .753 & .309 & & \\
\hline 3 & Extrinsic_position in society & .730 & & & \\
\hline 4 & $\begin{array}{l}\text { Extrinsic_reduction for acquiring a degree in } \\
\text { accounting profession }\end{array}$ & .667 & .354 & & \\
\hline 5 & Extrinsic_quality of study specialization & .621 & .405 & & \\
\hline 6 & $\begin{array}{l}\text { Intrinsic_accounting is the foundation of a } \\
\text { good economist }\end{array}$ & & .767 & & \\
\hline 7 & $\begin{array}{l}\text { Intrinsic_various opportunities for future } \\
\text { career development }\end{array}$ & .347 & .734 & & \\
\hline 8 & Intrinsic_personal enthusiasm and talent & & .727 & & \\
\hline 9 & Intrinsic_job satisfaction & .314 & .705 & & \\
\hline 10 & Intrinsic_possibility of employment & .393 & .590 & & \\
\hline 11 & $\begin{array}{l}\text { Interpersonal_influence of economists from } \\
\text { another field }\end{array}$ & & & .808 & \\
\hline 12 & $\begin{array}{l}\text { Interpersonal_influence of prominent } \\
\text { accounting practitioners }\end{array}$ & & & .781 & \\
\hline 13 & $\begin{array}{l}\text { Interpersonal_career conversation and } \\
\text { professional orientation }\end{array}$ & & & .701 & \\
\hline 14 & $\begin{array}{l}\text { Interpersonal_influence of teachers and } \\
\text { associates }\end{array}$ & & & .609 & .497 \\
\hline 15 & Interpersonal_influence of friends & & & & .867 \\
\hline 16 & Interpersonal_influence of parents & & & & .833 \\
\hline
\end{tabular}

Source: Authors' calculations.

The first factor, i.e., the latent variable, can be called "achievement". It consists of five extrinsic variables and explains 34.876 percent of the total variance in the data. It is defined by the following manifest variables:

- position in the company,

- level of future income (earnings),

- position in society,

- reduction of exams for acquiring a degree in the accounting profession, and

- quality of study specialization. 
The second factor can be called "job fulfillment", and it consists of five intrinsic variables and explains 14.78 percent of the variance in the data. The manifest variables that make it up are:

- accounting is the foundation of a good economist,

- various opportunities for future career development,

- personal enthusiasm and talent,

- job satisfaction, and

- employment opportunities.

The third factor represents the "influence of authorities in the field of science and profession" and consists of four interpersonal variables that explain 8.09 percent of the total variance in the data. The manifest variables that make it up are:

- the influence of economists from another field,

- the influence of prominent accounting practitioners,

- career conversation and professional orientation, and

- the influence of teachers and associates.

The fourth factor is the "influence of family and friends" and consists of two interpersonal variables that explain 6.78 percent of the total variance in the data. The manifest variables that make it up are:

- the influence of friends and

- parental influence.

\subsection{Time of Decision on Enrollment in Accounting}

The official promotion of the study specialization programs is done at most public higher education institutions in $\mathrm{BiH}$ in the third year of studies, just before the students select their specializations. Given the declining number of students, specializations at the faculties have rival positions. However, the following 
analysis of the time when the students made the decision to enroll in the field of accounting shows that 40.3 percent of the students chose the field before enrolling in the faculty of economics, 18.2 percent during the first year of college, 15.8 percent during the second year of college, and only one quarter, that is, 25.7 percent made this decision in the third year of college (Figure 4).

Figure 4: Time of Decision on Enrollment in Accounting

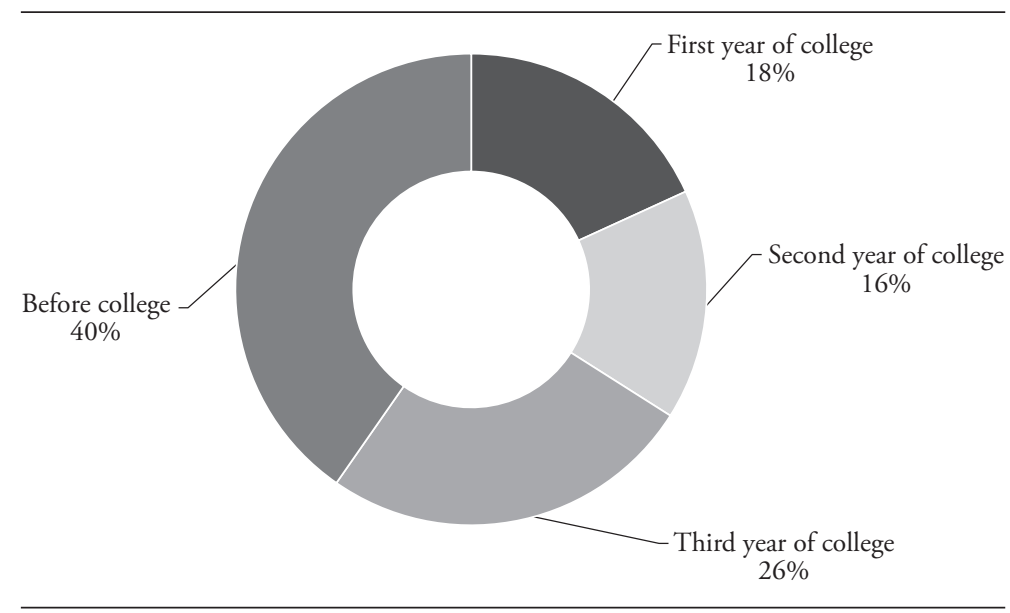

Source: Authors' calculations.

\subsection{Planned Training in the Field of Accounting}

The results of the research on planned training in the field of accounting, after the completion of the first cycle of studies, are presented in Table 6 . The largest number of students plan to obtain a certificate of accounting (41.50 percent), followed by 22.13 percent of respondents planning further education in the field of accounting, i.e., planning to obtain a master's degree or doctorate in accounting. About 14.62 percent of respondents plan to become certified auditors. 
Table 6: Planned Training in the Field of Accounting

\begin{tabular}{|c|c|c|c|}
\hline No. & Planned future training & $F$ & $\%$ \\
\hline 1 & Certified accountant & 105 & 41.50 \\
\hline 2 & Certified external auditor & 37 & 14.63 \\
\hline 3 & Internal auditor & 12 & 4.74 \\
\hline 4 & Certified forensic accountant & 11 & 4.35 \\
\hline 5 & Certified appraiser & 5 & 1.98 \\
\hline 6 & Bankruptcy trustee & 2 & 0.79 \\
\hline 7 & Court expert & 6 & 2.37 \\
\hline 8 & Actuary & 1 & 0.40 \\
\hline 9 & Master of economics in accounting & 56 & 22.13 \\
\hline 10 & Doctor of economics in accounting & 14 & 5.53 \\
\hline 11 & None of the above & 4 & 1.58 \\
\hline 12 & Total & 253 & 100.00 \\
\hline
\end{tabular}

Source: Authors' calculations.

It is interesting to point out that only 1.58 percent of respondents do not plan further training, while 98.42 percent plan some form of professional (70.75 percent) or scientific training (27.67 percent) in the future.

Also, when we consider the difference in attitudes between men and women, in the sense of future career development, we may conclude that a higher percentage of male students plan to do academic work, while a higher percentage of female students plan to work in the field. For example, a master of science in the field of accounting is a position desired by more than 32 percent of male respondents, and only a little over 19 percent of female respondents. At the same time, over 8 percent of male respondents wish to hold a $\mathrm{PhD}$ in social sciences, while this is true for only a little over 4 percent of female respondents. On the other hand, when regarding factors related to career development, female respondents predominate in this area. Approximately 16 percent of female students desire to become a certified auditor, while only 10 percent of male students desire this. Almost 44 percent of female students plan to become a certified accountant, while only 34 percent of male students plan to take this path. 


\section{Analysis and Discussion of Research Results}

In the total sample, female students make up 76.7 percent (194 respondents), while male students make up only 23.3 percent ( 59 respondents). The respondents come mainly from two groups of schools: 62.8 percent graduated from an economics high school, while 29.6 percent graduated from a gymnasium (general high school). The results of the descriptive statistical analysis show that intrinsic factors have the greatest influence on the choice of accounting specialization at public higher education institutions in $\mathrm{BiH}$. The average score for intrinsic factors is a total of 4.12, for extrinsic factors 3.98, while for interpersonal factors it is 2.59 . We also find through descriptive statistics that the variable "Various opportunities for future career development" has the highest average grade among intrinsic factors, the variable "Level of future income (earnings)" has the highest average grade among extrinsic factors, while the variable "Career conversation and professional orientation" has the highest average grade among interpersonal factors. By a nonparametric test for unpaired samples, we find that there is no statistically significant difference between the attitudes of women and men among the students. Factor analysis significantly changes the picture of the influence of individual factors on the choice of accounting specialization.

Based on the conducted factor analysis, we may conclude that there are four main influencing factors in the selection of accounting specialization by students at higher education institutions in $\mathrm{BiH}$. The first and most important factor is achievement or prestige, followed by job fulfillment, the influence of authorities in the field of science and profession, and the influence of parents and friends. After conducting a factor analysis, we get a completely new picture in terms of the importance of certain groups of factors in the selection of accounting specialization by students. Namely, the analysis shows that the first and most important factor that explains 34.88 percent of the total variance in the data refers to the latent extrinsic variable, followed by the latent intrinsic variable that explains a total of 14.78 percent of the variance in the data, and finally the latent interpersonal variable that explains 8.09 percent of the total variance in the data. 
At the same time, more than 77 percent of the students are women, and the students mostly graduated from economics high schools or gymnasiums. The largest percentage of students made the decision to enroll in accounting prior to enrolling at university, while about 75 percent of them, cumulatively, made this decision before enrolling in the third year of their studies. Over 98.42 percent of the students plan to continue their training in the field of accounting. In terms of professional training, the preferences are: obtaining a certificate for accountants (41.50 percent), certified auditors (14.62 percent), and internal auditors (4.74 percent). On the other hand, in terms of scientific training, 22.13 percent of respondents plan to obtain a master's degree, and 5.53 percent of respondents plan to obtain a doctorate in accounting.

\section{Conclusion}

Based on a study of key factors that influenced the choice of accounting specialization by students in public higher education institutions, we may conclude that the greatest role is played primarily by external (extrinsic) factors such as position in the company and level of future income. Achievement, that is, prestige in the company and society is the first motivating factor for students to opt for accounting. Students who have chosen to major in accounting expect money, awards, and recognition. They put their internal reasons for choosing the accounting profession in second place to the above-mentioned factors. These intrinsic factors are a person's opportunities for future career development, talent, and satisfaction in doing this type of work. This is followed by interpersonal influences, primarily the influence of authorities in the field of science and profession, and the influence of family and friends. Given that almost 60 percent of students decide which field to choose after enrolling at the university, there is a possibility that, through cooperation with the economy and organizing events that will bring together experts in accounting, both academic and professional, students can gain insight into the various types of possible future training, job descriptions, and work tasks, as well as the status that professionals have in 
organizations or society. The predominantly female part of the student population opts for accounting, primarily for work in the field. There is a higher percentage of male students who are more interested in academic work.

These research results can also be useful to professional groups in the field of accounting in terms of achieving their strategic goals. These strategic goals may relate to increasing or decreasing the number of accounting staff with certain certificates and licenses and the price of their services, viewed from the point of view of supply and demand.

The largest limitation of this research is the fact that we could not create a stratified sample that would be the sum of equal percentages of students in the sample from each public higher education institution in $\mathrm{BiH}$. Recommendations for future research in this area would be to consider the influence of personality traits on the choice of accounting specialization by students in relation to students of other specializations, and to explore differences in the perceptions of students and employees in the accounting profession regarding certain indicators of economic and social achievements. 


\section{Literature}

Abbasi, M. N., \& Sarwat, N. (2014). Factors inducing career choice: Comparative study of five leading professions in Pakistan. Pakistan Journal of Commerce \& Social Sciences, 8(3), 830-845. Retrieved from:

http://www.jespk.net/publications/211.pdf

Agarwala, T. (2008). Factors influencing career choice of management students in India. Career Development International, 13(4), 362-376.

doi: https://doi.org/10.1108/13620430810880844

Akter, M., \& Siraj, M. M. (2018). Factors affecting undergraduate students' intention to become a chartered accountant in Bangladesh. Asian Journal of Finance and Accounting, 10, 428-439. doi: https://doi.org/10.5296/ajfa.v10i1.13259

Azrinawati, M. R., Khalil, S. H., Saidin, N. Z., Kadir, N. A., \& Romaino, F. A. S. (2018). Reasons to choose chartered accountant as profession. IEBMC 2017 8th International Economics and Business Management Conference, The European Proceedings of Social \& Behavioural Sciences.

doi: https://doi.org/10.15405/epsbs.2018.07.02.15

Beynon, J., Toohey, K., \& Kishor, N. (1998). Do visible minority students of Chinese and South Asian ancestry want teaching as a career? Perceptions of some secondary school students in Vancouver, BC. Canadian Ethnic Studies, 30(2), 50-73. Retrieved from:

https://go.gale.com/ps/anonymous?id=GALE\%7CA82883535\&sid=googleScho lar\&v=2.1\&it $=r \&$ linkaccess $=$ abs \&issn $=00083496 \& p=A O N E \& s w=w$

Byrne, M., Flood, B., Hassall, T., Joyce, J., Montano, J. L., González, J. G., \& Germanou, E. T. (2012). Motivations, expectations and preparedness for higher education: A study of accounting students in Ireland, the UK, Spain and Greece. Accounting Forum, 36(2), 134-144.

doi: https://doi.org/10.1016/j.accfor.2011.12.001

Carpenter, P. G., \& Foster, W. J. (1977). Time of decision as a factor in deciding to teach. Probe: A Journal of Educational Issues, 6, 6-13. 
Dibabe, T. M., Wubie, A. W., \& Wondmagegn, G. A. (2015). Factors that affect students' career choice in accounting: A case of Bahir Dar University students. Research Journal of Finance and Accounting, 6(5), 146-153.

Hartati, N. (2019). The effect of motivation on the interest of accounting students to follow accounting professional education. Accounting and Finance Review Journal, 4(3), 79-86. Retrieved from:

https://www.academia.edu/41451573/Accounting_and_Finance_Review_The_ Effect_of_Motivation_on_the_Interest_of_Accounting_Students_to_Follow_ Accounting_Professional_Education

Hartutik, I. D., Hendra, K., \& Masitoh, E. (2016). How does student interest effect participation in pursuing education for the accounting profession (PPAk)? Shirkah: Journal of Economics and Business, 1(2), 207-222.

doi: https://doi.org/10.22515/shirkah.v1i2.42

Hashim, H. M., \& Embong, A. M. (2015). Parental and peer influences upon accounting as a subject and accountancy as a career. Journal of Economics, Business and Management, 3(2), 252-256.

doi: https://doi.org/10.7763/JOEBM.2015.V3.189

Ibrahim, S. N., Pauzi, N. F., Shamsudin, A., Karim, M. S., \& Ahmad, K. (2017). Motivating factors for sustainable accountant potentials in Malaysia. SHS Web of Conferences, 36, 00035. doi: https://doi.org/10.1051/SHSCONF/20173600035

Jamil, M. I. M. (2019). The factors influencing the career choice of university students: A descriptive analysis of pure science and social science students in Universiti Brunei Darussalam. The 1st International Conference on Business, Management and Information Systems 2019 (pp. 566-588).

Kamran, A., Kazi Feroz, A., \& Manzurul, A. (1997). An empirical study of factors affecting accounting students' career choice in New Zealand. Accounting Education, 6(4), 325-335. doi: https://doi.org/10.1080/096392897331398

Marinas, L. E., Igret, R. S., Marinaș, C. V., \& Prioteasa, E. (2016). Factors influencing career choice: The Romanian business and administration students' experience. European Journal of Sustainable Development, 5(3), 267-278. doi: https://doi.org/10.14207/ejsd.2016.v5n3p267 
Nimra, S., Nawaz, A., \& SamiUllah, S. (2019). Factors influencing career choices. IBT Journal of Business Studies, 15(1), 33-46. doi: https://doi.org/10.46745/ilma.jbs.2019.15.01.03

Nwobi, N., Uzoekwe, H., Ojo, T., \& Odo, C. (2020). Influence of intrinsic, extrinsic and interpersonal factors on vocational choice of secondary school students in Ogidi education zone of Anambra State. Journal of Guidance and Counselling Studies, 4(2), 282-292.

Nwobu, O., Faboyede, S., \& Oyewo, B. (2015). Accounting students' choice to pursue a career in the industry or academics: Lessons from selected private Nigerian universities. Proceedings of ICERI2015 Conference, 16th-18th November 2015, Seville, Spain (pp. 1252-1260). Retrieved from:

https://core.ac.uk/download/pdf/32226843.pdf

Porter, J., \& Woolley, D. (2014). An examination of the factors affecting students' decision to major in accounting. International Journal of Accounting and Taxation, 2(4), 1-22. doi: https://doi.org/10.15640/ijat.v2n4a1

Rababah, A. (2016). Factors influencing the students' choice of accounting as a major: The case of X university in United Arab Emirates. International Business Research, 9(10), 25-32. doi: https://doi.org/10.5539/ibr.v9n10p25

Theresa, L. D. (2015). Factors that inform students' choice of study and career. Journal of Education and Practice, 6(27), 43-49.

Țicoi, C., \& Albu, N. (2018). What factors affect the choice of accounting as a career? The case of Romania. Accounting and Management Information Systems, 17(1), 137-152. doi: https://doi.org/10.24818/jamis.2018.01007

Van Zyl, C., \& de Villiers, C. (2011). Why some students choose to become chartered accountants (and others do not). Meditari Accountancy Research, 19(1/2), 56-74. doi: https://doi.org/10.1108/10222521111178637 